The author
offers a new
way to look
at English.

\title{
From Tripod to Cosmos: A New Metaphor for the Language Arts \\ Lawrence A. Baines
}

"So it has been, so it now is, so it shall be, profession without end, amen."

(Ed Farrell, "What Is

English?," 122)

nce upon a time, a favorite metaphor for the language arts was the tripod. Unlike the recentlyreleased standards document, a teacher could easily remember its three components-language, literature, and composition-and could arrange instruction so that all three components were included in the course. Predictably, the tripod model grew out of favor because it was perceived to be a rigid structure which isolated the English curriculum into distinct parts (Bushman and Bushman 1994; Grommon 1991; Simmons, Shafer, and West 1976). According to Stephen Tchudi (1989), "In practice, it was found that most teachers taught each leg of the tripod as if they were mutually exclusive components" (351). Later, the work of Jim Moffett, James Britton, and others, inspired by the Dartmouth Conference of 1966, expanded the idea of the tripod to include oral language skills, speech, and drama.

\section{THE NEW NATIONAL STANDARDS IN LANGUAGE ARTS}

Much of the furor surrounding the release of the IRA/NCTE national standards in the language arts has to do with their failure to specify what should be covered in a language arts classroom. While the standards mention texts, language, research, and writing, the writers of the standards chose to refrain from offering up a checklist detailing what a student should know. Edward Fry (1996) has called the standards document "a bowl of mush ... about vague educational jargon and process" (40). Indeed, in reading the standards, a beginning teacher might have a difficult time attempting to create lesson plans in which "students [will] use spoken, written, and visual language to accomplish their own purposes" (Wilhelm 1996, ix).
Visual language? Does that entail fingerpainting or ballet?

A student's own purposes? A seasoned teacher of exuberant middle school students might be skeptical of building a curriculum around what middle school students might consider important-how to create spitwads that stick well against the ceiling, how to color hair using felt-tipped markers, how to create farting noises that sound real, how to drive Coach Vasquez crazy ... While such topics might be great tools for periodically stimulating student writing, they are probably not substantive enough to build upon for an ongoing, well-rounded curriculum.

To their credit, the creators of the standards realized that specifying minimum standards could take the life and art out of teaching. If minimum competencies were mandated, then they likely would become the curriculum, and good teaching would become equated with good numbers on language arts grade-level exit exams. Aesthetics and individual attention would become superfluous, considered only after minimum competencies had been attained.

Of course, defining the language arts curriculum has been the subject of great debate over time:

The catch-all character of many English programs results in confusion of purpose and diffusion of responsibilities, both inimical to good instruction. The scope of the English program [should] be defined as the study of language, literature, and composition, written and oral, and that matters not clearly related to such study be excluded from it. (Commission on English 1965, 13)

The English teacher, as an expert on language, cannot confine himself to the traditional quadrivium of language arts skills (reading, writing, listening, and speaking); he must be dynamically concerned with the thinking processes that lie beneath them. (Hillocks, McCabe, and McCampbell 1971, 12)

The department of English and its classroom teachers are responsible for 
students' general knowledge of English language and literature, as well as for fluency in reading, writing, speaking, listening, and thinking. (LloydJones and Lunsford 1989, 19)

As English curricula set out skills, processes, modes, and goals, listed as discrete items to be covered within a year of study, yet without a related informing and unifying context, they project a fragmented view of the subject. (Britton and Chorny 1991, 112)

Reading, writing, and oral language are the bedrock subjects of the curriculum, for they develop the competencies on which virtually all subsequent instruction and learning depends. (Squire 1995, 71)

As the language arts curriculum evolves and expands, the expectations for language arts teachers seem to have grown more nebulous. Unfortunately, in pinning down the amorphousness of the language arts curriculum, the new standards document has helped little. If one consults teachers concerning what they say they teach; professors, administrators, standards documents, and textbooks for what they think teachers should teach; and researchers and students for what they think teachers really teach, one hears different stories. At the least, a teacher of the twenty-first century will be expected to have considerably broader expertise than the teacher of only a decade ago. Although the tripod approach may still reign in a few classrooms, even the scope and content of literature, language, and composition have become transformed from the days of yore.

\section{THE CURRICULUM \\ BEYOND THE TRIPOD}

In order to discover what curriculum beyond the tripod is expected of teachers of language arts today, I conferred with various teachers, administrators, and researchers and consulted texts concerned with the teaching of the language arts at the secondary level. While teachers, administrators, and writers consistently mentioned the components of the tripod (literature, language, and composition), they also mentioned one or more of these five components: speech and drama, critical thinking, technology, media literacy, and interdisciplinary studies. Thus, from the evidence I gathered, the contemporary language arts curriculum encompasses the following eight areas:

- Literature

- Language

- Composition

- Speech and drama

- Critical thinking

- Technology

- Media literacy

- Interdisciplinary studies

To verify the claim that the curriculum has evolved into eight overlapping components, I examined fifteen important books related to the teaching of the language arts, beginning with The Commission on English's report in 1965 and ending with Standards in Practice 9-12 (Smagorinsky 1986). As can be seen from the two tables, the conception of the language arts has continued to expand

\begin{tabular}{|c|c|c|c|c|c|c|}
\hline & $\begin{array}{l}\text { Freedom and } \\
\text { Discipline, } \\
\text { Commission } \\
\text { on English } \\
\quad(1965)\end{array}$ & $\begin{array}{l}\text { High School } \\
\text { English Today, } \\
\text { Squire and } \\
\text { Applebee } \\
\text { (1968) }\end{array}$ & $\begin{array}{l}\text { Dynamics of } \\
\text { English, } \\
\text { Hillocks, } \\
\text { McCabe, and } \\
\text { McCampbell } \\
\text { (1971) }\end{array}$ & $\begin{array}{c}\text { Decisions } \\
\text { about } \\
\text { English, } \\
\text { Simmons, } \\
\text { Shafer, and } \\
\text { West (1976) }\end{array}$ & $\begin{array}{c}\text { Coalition } \\
\text { Conference, } \\
\text { Lloyd-Jones } \\
\text { and } \\
\text { Lunsford } \\
(1989)\end{array}$ & $\begin{array}{c}\text { Explorations } \\
\text { in Teaching } \\
\text { of English, } \\
\text { Tchudi and } \\
\text { Mitchell } \\
\text { (1989) }\end{array}$ \\
\hline language & yes & yes & yes & yes & yes & yes \\
\hline literature & yes & yes & yes & yes & yes & yes \\
\hline composition & yes & yes & yes & yes & yes & yes \\
\hline speech and drama & yes & yes & yes & yes & yes & yes \\
\hline critical thinking & & & & & yes & \\
\hline technology & & yes & & & & yes \\
\hline media literacy & & & & yes & yes & yes \\
\hline $\begin{array}{l}\text { interdisciplinary } \\
\text { studies }\end{array}$ & & & & & & yes \\
\hline
\end{tabular}

TABLE 1. Curricular areas evident in some books on Language Arts Education (1965-1989) 


\begin{tabular}{|c|c|c|c|c|c|c|c|}
\hline & $\begin{array}{l}\text { Handbook of } \\
\text { Research on } \\
\text { Teaching, } \\
\text { Britton and } \\
\text { Chorny } \\
\text { (1991) }\end{array}$ & $\begin{array}{l}\text { Story- } \\
\text { making } \\
\text { and } \\
\text { Drama, } \\
\text { King } \\
(1993)\end{array}$ & $\begin{array}{l}\text { Teaching } \\
\text { English in } \\
\text { Middle/High, } \\
\text { Maxwell } \\
\text { and Miser } \\
\text { (1993) }\end{array}$ & $\begin{array}{l}\text { Bridging } \\
\text { English, } \\
\text { Milner } \\
\text { and } \\
\text { Milner } \\
\text { (1993) }\end{array}$ & $\begin{array}{l}\text { Teaching } \\
\text { English } \\
\text { Creatively, } \\
\text { Bushman } \\
\text { and } \\
\text { Bushman } \\
\text { (1994) }\end{array}$ & $\begin{array}{l}\text { Making the } \\
\text { Journey, } \\
\text { Christenbury } \\
\text { (1994) }\end{array}$ & $\begin{array}{l}\text { Standards in } \\
\text { Practice } \\
\text { (9-12), } \\
\text { Smagorinsky } \\
\text { (1996) }\end{array}$ \\
\hline language & yes & yes & yes & yes & yes & yes & yes \\
\hline literature & yes & yes & yes & yes & yes & yes & yes \\
\hline composition & yes & yes & yes & yes & yes & yes & yes \\
\hline speech and drama & yes & yes & yes & yes & yes & yes & yes \\
\hline critical thinking & yes & yes & & yes & yes & yes & yes \\
\hline technology & yes & & yes & yes & & yes & yes \\
\hline media literacy & yes & yes & & yes & & yes & yes \\
\hline $\begin{array}{l}\text { interdisciplinary } \\
\text { studies }\end{array}$ & yes & yes & yes & & yes & & yes \\
\hline
\end{tabular}

TABLE 2. Curricular areas evident in some books on Language Arts Education (1991-1996)

over time. Since the late 1980s, most textbooks on the teaching of the language arts have gone beyond the conception of the tripod, although few of them have explicitly identified the new and emerging areas of study.

In the remainder of this article, I offer a rationale for cosmos as a new metaphor for the language arts, discuss the content of each curricular area, and provide a glimpse at some relevant texts and research.

\section{SEARCHING FOR A NEW METAPHOR: LANGUAGE ARTS AS THE COSMOS?}

Selecting a proper symbol for the language arts should not be taken lightly. Of metaphors, Sharon Pugh, Jean Hicks, Marcia Davis, and Tonya Venstra (1992) have written that "through metaphorical thinking, divergent meanings become unified into the underlying patterns that constitute our conceptual understanding of reality" (3). An initial thought was that a new metaphor for the language arts might be an octopod. After some consideration, I rejected octopod for two reasons: a) the image of a mechanical device with eight separate legs did not seem to fit with the organic nature of the language arts and the possibilities for teaching multiple topics concurrently; b) the association of octopod with octopus might conjure up sinister images for some persons.

Next, I drew a circle and wrote language arts in the middle of it. Then, I drew eight overlapping ellipses around the center circle and labeled each accordingly. When I fin- ished, my drawing looked like a flower with eight petals.

Not being much of a botanist, I looked through a few books of flower classifications and discovered that I had actually drawn something that looked quite a bit like the cosmos, a member of the Aster family of flowers. A cosmos is hardy, often has eight petals, grows to be 5-9 feet tall, blooms in all colors (except blue), and dies after prolonged exposure to the cold. An apt metaphor for the "flowering" of learning, cosmos connotes a delicate, natural, aesthetic experience, with the possibility for both blossoms and barrenness. Of course, cosmos has the added appeal of also meaning, "the universe considered as a harmonious and organized system" (Neufeldt 1994, 314). Indeed, one reason for using cosmos as a new metaphor is to help give a sense of unity to the complexities of teaching the language arts.

\section{THE CURRICULAR AREAS OF THE COSMOS}

\section{Literature: Reading, Interpreting, Relating}

The teaching of literature today involves more than simply covering the classics. The realms of literature have broadened to include young adult literature, nonfiction, multicultural books, and multi-media experiences. So pressing have legislators perceived the need to expand the literary canon that many states have mandated that African American writers, Latino authors, and the literature of the Holocaust be written into the curriculum for each year of high school. 
Many reformers and researchers in the language arts advocate allotting large, uninterrupted chunks of time for reading during the school day so that students are given the opportunity for extended encounters with written texts (Atwell 1987; Christenbury 1994; Probst 1988; Rief 1992; Rosenblatt 1978). In this manner, students are encouraged to read a variety of publications, some of which are required and some of which are self-selected. Of central importance for the teacher is the fostering of a congenial community of readers within the classroom whose members discuss, analyze, and share their reactions to texts (Andrasick 1990; Applebee 1996; Beach 1993; Bleich 1988; Fish 1980; Holland 1989; Iser 1978).

Over the past 30 years, the New Critical approach of the "objective correlative" has given way to the individual responses of readers and the ways that students may discover and support their interpretations of texts. A teacher's classroom and the school library should house a wide variety of fiction and nonfiction books of varying difficulty (Bomer 1995; Donelson and Nilsen 1993; Foster 1993; Hirsch 1987; Simmons and Delazain 1992).

Today, the Internet offers access to thousands of unexpurgated books, as the stated purpose of projects such as the Gutenberg Project is to make some of the world's greatest books accessible online. A recent search on William Shakespeare pulled up 17,000 hits, among them The Skinhead's Shakespeare, The Complete Shakespeare (an unexpurgated on-line library of all of his plays) and Shakespeare Illustrated (a collection of paintings by various artists depicting scenes from plays). In recent years, many new CD-ROMs have been introduced. Dedicated to the lives of writers such as John Steinbeck, Toni Morrison, Jack Kerouac, and Ernest Hemingway, these multi-media CD-ROMs combine unabridged texts with photos, interviews, and artwork that could enrich the literary experience for students.

\section{Language: Decoding, Acquiring, Integrating}

The teaching of language involves the teaching of spelling, vocabulary, the history of the language, diction, onomastics, dialects, syntax, register, connotation, grammar, mechanics, semantics, pronunciation, decoding, and other topics. Because linguistics is rife with possible controversies, such as the continuing debate over dialect and standard usage, the use of slang and colloquialisms, and the effectiveness of teaching vocabulary and spelling, many teachers find that language study is their least favorite topic and focus instead on composition and literature (Claywell 1995).

Yet, language is the foundation upon which most learning is built. Of language, George Steiner (1967) has written, "So far, in history, it is language that has been the vessel of human grace and the prime carrier of civilization" (109). John Young (1991) has shown how totalitarian leaders such as Hitler and Idi Amin have attempted to manipulate language for destructive ends as well. Indeed, a knowledge of the appropriate uses of language under varying conditions for different purposes and audiences (a business letter, a shopping list, a conversation on the telephone with a friend, a job interview, a paper suitable for publication in an academic journal) would seem indispensable in our increasingly specialized, highly diverse global village.

An effective method of learning how to speak and write for specific purposes and varied audiences is to arrange the curriculum so that students are required to actively manipulate words, mechanics, and grammar to achieve desired results (Altick and Lunsford 1984; Andrews 1993; Hayakawa 1990; Irmscher 1979; Nagy 1988; Vygotsky 1962). Timely, sincere, and accurate reactions to language activities from peers and the teacher help foster a stimulating, linguistically-rich, fun environment for language learning (Britton 1970; Bishop 1995; Mellon 1981; Wolfram 1991). In addition, with the proliferation of images, icons, and computer clip art, students need to know how the propensities of language change with media (Baines 1996; Birkerts 1993; Clark 1983; Kozma 1991 and 1994). For example, a student might have different understandings of the word bungalow when he/she reads it in a Dickens novel, views bungalow accompanied by an icon of a two-story Cape Cod structure on a computer screen, or hears bungalow in a film documentary describing the William Randolph Hearst mansion.

\section{Composition: Writing, Editing, Publishing}

Over the past 25 years or so, initiatives such as the Bay Area Writing Project have 
shifted the focus of writing instruction from finished products to the processes of planning, composing, revising, and publishing. Rather than have students write prescriptive, short, academic responses, contemporary teachers of writing plan for students to write in a variety of modes (description, narration, evaluation, classification) for different aims (expressive, persuasive, informative, literary) and for different audiences (peers, elementary-age students, parents, journal editors). So that students will come to understand the requisites of writing for real audiences, students receive ample opportunities to write for audiences other than the teacher-as-sole-evaluator (Britton et al. 1975; Haas-Dyson and Freedman 1991; Kinneavy 1971; Kirby, Liner, and Vinz 1988).

Most advocates of writing as a process plan for large blocks of uninterrupted time for writing, use individual conferences exten-

The tripod model grew out of favor because it was perceived to be a rigid structure which isolated the English curriculum into distinct parts. sively, and make sharing and publishing an integral part of daily classroom activity (Elbow 1973; Emig 1971; Hillocks 1986; Goldberg 1991; Lamont 1994; Murray 1987). Because students are often unaware of many literary forms, it also falls under the aegis of the teacher of composition to acquaint students with them (novel, short story, epic poem, tall tale, myth, haiku, screenplay, one-act play, technical paper, essay) and how form relates to mode, aim, audience, and media.

Undeniably, the teaching of composition has been forever altered by the computer (Hawisher 1996; Selfe 1994; Willis, Stephens, and Matthew 1996; Wresch 1991). Most newly constructed school buildings have both a set of computers in classrooms as well as separate areas that serve as labs where students can write, edit, and publish their work. Because language arts departments are the most frequent users of computers (Quality Education Data 1996), it usually falls upon language arts teachers to be familiar with various software programs, especially wordprocessing programs. Teachers are asked to guide students in computer use if they do not know how to use them already and to direct the students to network resources.

Because writing for nonprint media has been the most profitable avenue for professional writers in the twentieth century (and promises to become even more lucrative in the twenty-first century), teachers of compo- sition must also consider providing environments in which students engage in writing for media such as film, television, Internet, and CD-ROM (Baines and Dial 1995; Warren, Williams, and Sutz 1996; Hamilton 1990; Roberts 1996).

\section{Speech and Drama: \\ Speaking, Listening, Performing}

That speech and drama have been largely neglected in language arts classrooms over the years has been the subject of various studies (Wagner 1995) and books (King 1993; O'Keefe 1995). Yet, facility with oral language is a tangible indication of a person's language competence and is likely the aspect of language arts that adolescents use most often. Britton (1970) has called oral discourse the phenomenon of speech shaping thought at the point of utterance. According to Moffett (1968), a conversation is actually a complex process whereby "initial plans, plots, incidents, instances, concepts, and generalizations become refined, related, complicated, and concatenated" (170).

Indeed, face-to-face conversation is still the most common form of communication among persons in our society, yet few language arts teachers ever consider giving instruction on how to create persuasive speeches, how to listen properly, how to offer useful criticisms, or how to use the voice and body to achieve a desired effect (Fernandez 1969; Herman and Ratliffe 1972, Moffett and Wagner 1992; Holdzkom, Reed, Porter, and Rubin 1985; Spolin 1983). As with writing, appropriate elocution and diction are dependent upon audience and purpose, and effort should be devoted to having students develop a repertoire of effective methods of oral expression.

Of course, the listener plays as crucial a role as the speaker in oral discourse. Seasoned teachers would likely not be surprised to learn that researchers have found that some students experience great difficulty listening effectively. In fact, from the available evidence, it appears that students rarely get the opportunities to speak at any length in any of their classes (Adler 1983; Cooper 1985; Roach and Wyatt 1988, Nystrand 1993; Csikszentmihalyi and Larson 1984; Csikszentmihalyi, Rathunde, and Whalen 1993).

Certainly, the affordability and availability of camcorders and VCRs allow teachers to 
easily record activities such as presentations, speeches, and dramatic performances. By subsequently viewing videotapes, students can review and examine their own and their peers' effectiveness. In addition, a videotaped performance is archivable and may serve as an authentic assessment of a student's strengths and weaknesses (Baines 1995).

\section{Critical Thinking: Studying, Strategizing, Evaluating}

While critical thinking is imbedded in each of the seven other components of the cosmos, there are specific methods by which students can improve their scores on standardized tests; learn vocabulary more enduringly; listen, read, write, speak, and think more effectively. Recently, many schools have begun offering pre-SAT study classes as part of the regular high school curricula or mandated that critical thinking skills be taught during homeroom at some point in every school day. Critical thinking sections have even begun appearing in publications such as Read.

Sandra Stotsky (1991) views critical thinking as best served through the pursuit of research projects and papers, where students are required to synthesize reading, writing, and researching. The research assignment in which students must categorize, organize, and reconceptualize "is probably the most important vehicle that teachers have for fostering independent critical thinking" (194) according to Stotsky. In contrast, Vincent Ruggiero (1985) views conversation and dialogue as keys in the development of critical thinking skills.

The Seven Habits of Highly Effective People (Covey 1989) and Dimensions of Learning (Marzano et al. 1992) are two texts that have gained popularity with teacher inservice providers because they offer some critical thinking techniques that purport to bolster learning and increase student achievement scores. Peter Smagorinsky (1987, 1991, 1996) consistently advocates the integration of critical thinking exercises into the language arts curricula. For example, in Expressions (1991), one exercise requires that groups of students create a definition of progress based upon two contrasting scenarios-the development of computers to perform routine tasks versus the likelihood that such technological innovation would eliminate jobs, especially unskilled labor. The current trend towards teaching thinking skills is reminiscent of the controversial Values Clarification (Simon, Howe, and Kirschenbaum 1972) movement in the early 1970s in which students were asked to think beyond superficialities and to base their conclusions upon conscious choice and logical analysis.

However useful the teaching of thinking skills might be for some students, some recent research (Baines 1996) indicates that, in practice, most teachers turn the teaching of critical thinking into study halls or a series of perfunctory worksheets. While gifted and talented programs continue to emphasize critical thinking skills in their programs (VanTassel-Baska, Johnson, and Boyce 1996), other tracks have been reluctant to ascribe to the idea that such skills are teachable. Outside of the academic community, international organizations such as SEAL (Society for Effective Affective Learning 1995), Sylvan, and Kaplan continue to thrive as they offer accelerated learning programs that meld the language arts with psychology, philosophy, and the sciences to the public at relatively exorbitant prices.

\section{Technology: Computing, Researching, Presenting}

Some of the most vituperative criticisms of public education have been that schools have become antiquated institutions where teachers still scrawl out messages with chalk rock to communicate with students. However valid such criticisms might have been at one time, today most schools have invested huge sums of money and personnel in technology-especially computers. In 1983-1984, the average number of students per computer was 125. By 1995-1996, the number has diminished to an average of ten students per computer. Today, over $98 \%$ of schools have at least some computers, 84\% use cable in at least part of the instructional day, and over 50\% have CD-ROM capabilities. Sixty-one percent of high schools are connected via LANs, Local Area Networks (Quality Education Data 1996). Despite the emphasis on technology in schools, administrators still perceive a dearth of technologically-competent teachers (Ponessa 1996).

Whether teachers espouse or eschew technology, computers are irrevocably changing the world. The consensus opinion is that "each generation will become more digital than the preceding one" (Negroponte 1995). 
The ability to immediately call up any one of thousands of books online, to tour a gallery of paintings by American artists of the 1920s, to view the works of Japanese calligraphers of the thirteenth century, to listen to a speech by Martin Luther King, Jr., to initiate an electronic mail relationship with students in Armenia, Taiwan, or New Zealand, to discuss recent news events with crowds of strangers from around the globe-these are possible now via a series of keystrokes.

As research tools, computers, CD-ROMs, and the Internet offer phenomenal possibilities (Hawisher and LeBlanc 1989; Williams 1996; Willis, Stevens, and Matthew, 1996; Wresch 1991). Another strength of these new media is that they offer icons, graphics, photos, sound, and text in one convenient, highly accessible package. Although great headway has been made in making computers more user-friendly, much of their operation remains machine-dependent and mysterious to those unfamiliar with their workings. A simple task such as checking one's e-mail can seem insurmountably complex to a teacher whose previous experience with machines has been an electronic typewriter.

One of the more interesting findings concerning the uses of nonprint media has been the research of Joseph Walther (1995), who has noted that computer-mediated communication tends to be more open, personal, and visceral than face-to-face interaction. As with speech and whole language, the presentation capabilities of computers with software programs such as Persuasion, Inspiration, Power Point, Hypercard, and Hyperstudio have gone underutilized by teachers of the language arts. Instead of writing a paper solely to the teachers as evaluators, students could write and present a multimedia literary presentation, save it on a 3.5 inch disk, copy it to the school's home page so that anyone on the Internet could potentially view it, then submit it to an electronic — or traditional—publisher.

\section{Media Literacy: Selecting, Viewing, Analyzing}

Some recent books that have detailed the successes that tobacco companies have had in using advertising to encourage children to take up smoking have helped add urgency to the argument that students should learn how reality is constructed, reported, and packaged in America. Certainly, Americans seem obsessed by using electronic media to view all that is lurid, tragic, or sensational as documented by news agencies and as acted out in various entertainments. On television, the bloody Rodney King affair was supplanted by the Bobbitt penis mutilation affair, which was supplanted by the Menendez trial, which was supplanted by the O.J. Simpson trial (Darden 1996; Dershowitz 1996; Shapiro 1996; Simpson 1996), which was supplanted by various natural disasters, plane crashes, and the bombing at the Olympics. Over time, television has become more sexual and more violent, while its sponsors have used increasingly sophisticated appeals to popularity, sex, love, and God to sell us beer, toothpaste, and feminine deodorant spray.

Although organizations such as the National Telemedium Council, The Center for Media Literacy, and NCTE's Assembly of Media Arts continue to lobby for its inclusion, media literacy has been on the fringe of respectability ever since Robert Neal encouraged teachers of English to use film "with all the optimistic faith summonable, in order not to regard it [the motion picture] as excessively satanic" (658) in 1913. As of yet, media literacy has not been able to shake its reputation as evil, irrelevant, and anti-intellectual.

Media literacy may involve one or more of the following:

1. Using content recorded on film, television, photography, and nonprint media that correlates to the language arts curriculum, especially literature;

2. Studying how electronic messages are constructed (that is, camera angles, dialogue, editing procedures, director options, the use of music and background, aesthetics);

3. Investigating the degree to which film, video, and television reflects the values and history of the culture in which it was created (semiotics);

4. Requiring that students use nonprint media as part of their coursework for language arts (shooting a film, presenting television clips, creating video collages);

5. Having students examine the business rationale and marketing of nonprint media: films, videos, advertisements, and television shows (target audience, profitability, corporate associations and backing).

If media literacy occurs to any extent in language arts classrooms, it is most commonly in the guise of showing the movie after reading the book ( 1 , above; Foster 1993). Most media literacy reformers (Considine and Haley 1992; Costanzo 1992; Fox 1994; Gerbner and Signorelli 1988; Gerbner, 
Mowlana, and Schiller 1992; Morris 1993) focus upon how electronic messages are constructed (2, above), while semiotics (3, above) has become the playing field of colleges of English, communications, and anthropology. Yet, the most intriguing educational possibilities might involve having students create their own multimedia projects (4, above; Barefield 1996) and having students investigate the profit motives of various media conglomerates (5, above). For example, few teachers or students realize that one corporation-Viacom-owns textbook and tradebook publishing houses such as Simon $\&$ Schuster, Prentice Hall, and Pocket Books; numerous cable channels (Showtime, MTV, The Movie Channel, and others); production companies, independent television stations, and radio stations (Viacom is the sixth largest holder of radio stations in the country). While such clout does not necessarily translate into malevolence, knowledge of Viacom's vast media empire might inform the rationale behind their advertising, distribution choices, and media campaigns.

\section{Interdisciplinary Studies: Connecting, Synthesizing, Appreciating}

The National Middle School Association curriculum guidelines (1991) require that a middle school teacher "understand interrelationships among fields of knowledge" and "adapt curriculum and instruction to the learning patterns of each student" (6). Of course, such malleability of expertise would require language arts teachers to possess expertise in a variety of fields. The problem with the single subject approach, according to James Beane (1995), is that it "offers little more than a disconnected and incoherent assortment of facts and skills" (618).

To be sure, at the middle school level, the adoption of block scheduling, longer school days, student-centered learning, and team teaching have created the need for a new certification-the middle school endorsement, a kind of multi-subject certification that encourages the fusion of two or more traditionally separate disciplines, especially with the language arts (Lewis 1995). For the past ten years, an exemplar of the interdisciplinary unit has been The Voyage of the Mimi (Hendrick 1985), a successful, middle level, multi-media program that combines film, reading, and writing activities with the study of oceanography, earth science, and biology.
During the Mimi unit, a student might read a selection about water pressure, watch a film excerpt, write a paper on what problems an engineer designing submarines might consider, then perform an experiment that demonstrates some properties of water pressure in a single class period.

Certainly, the work of Howard Gardner $(1983,1993)$ has helped give credence to the multi-disciplinary approach to curriculum development in high school. Other interdisciplinary units for high school have been created by Brooke Workman, who wrote Teaching the Decades (1980) and Teaching the Sixties (1992). These units require students to examine, research, and contemplate the popular culture, history, architecture, art, poetry, plays, dance, and music of America at different periods.

While interdisciplinary units may be novel to some, teachers of the humanities at the high school level have integrated content from many fields for years. The series of books and cassettes entitled The Humanistic Tradition (Fiero 1995) epitomizes how literature, music, technology, history, religion, and art may be integrated into a single unit for study. However, as Philip Panaritis (1995) has pointed out, teaching interdisciplinary units effectively requires a well-trained, talented staff of teachers, a supportive administration, and a willing set of students. Schools who score poorly on achievement exams are more likely to pare down their interdisciplinary and elective offerings and eliminate sports, art, music, and extracurricular activities (Kozol 1991). Yet, Elliot Eisner (1991) and Maxine Greene (1995) have emphasized that the arts and extracurricular activities hold the potential for sparking creativity in students that would otherwise go unnoticed: "Encounters with the arts nurture and sometimes provoke the growth of individuals who reach out to one another as they seek clearings in their experience and try to live more ardently in the world" (Greene 382).

\section{CONCLUSION}

"Those not busy being born are busy dying." (Bob Dylan)

Since the Committee of Ten met in 1894 to frame the curriculum for secondary schools in the United States, the study of English has been the only subject mandated for all four years of high school. Although

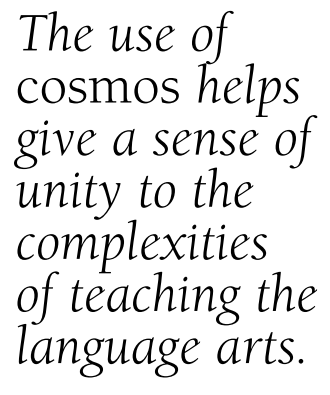




\section{Unfortunately, in pinning down the amorphousness of the language arts curriculum, the new standards document has helped little.}

English as a discipline has managed to endure for more than a century, conceptions of literacy have changed dramatically over time (Kaestle, Damon-Moore, Stedman, Tinsley, and Trollinger 1991).

In the twenty-first century, no longer will it be sufficient that "the scope of the English program be defined as the study of language, literature, and composition" (Commission on English 1965, 13). In the fast paced, highly competitive, global village of tomorrow, the language arts must adapt or face extinction. The cosmos-language, literature, composition, oral language, critical thinking, technology, media literacy, and interdisciplinary studies - is a metaphor that attempts to describe the language arts at the close of the twentieth century. Considering the language arts as the eight-petaled cosmos (a symbol purposefully rife with innuendo) may help provide a structure for teachers who are seeking creative approaches to the sometimes amorphous worlds of standards and accountability. Of course, a decade or two from now, the cosmos may likely need to be replaced by a metaphor more appropriate to the literacies needed to function and thrive in that new era.

\section{Works Cited}

\section{Introduction}

Britton, James. 1970. Language and Learning. New York: Viking.

Britton, James, Tony Burgess, Nancy Martin, Alex McLeod, and Harold Rosen. 1975. The Development of Writing Abilities (11-18). London: Macmillan.

Britton, James and Merron Chorny. 1991. "Current Issues and Future Directions." Handbook of Research on Teaching the English Language Arts. James Flood, Julie Jensen, Diane Lapp, and James Squire, eds. New York: Macmillan.

Bushman, John and Kay Bushman. 1994. Teaching English Creatively. Springfield, IL: Thomas Books.

Christenbury, Leila. 1994. Making the Journey. Portsmouth, NH: Heinemann.

Commission on English. 1965. Freedom and Discipline in English. New York: College Entrance Examination Board.

Farrell, Ed. 1991. "What is English?" Journal of Teaching Writing 10.2: 111-122.

Fry, Edward. 1996. "These are Not Standards; They're a Bowl of Mush." Reading Today (Jun./Jul.): 40.

Grommon, Alfred. 1991. "A History of English Language Arts Teacher Education." Handbook of Research on Teaching the English Lan- guage Arts. James Flood, Julie Jensen, Diane Lapp, and James Squire, eds. New York: Macmillan.

Hillocks, George, Bernard McCabe, and James McCampbell. 1971. The Dynamics of English Instruction. New York: Random House.

King, Nancy. 1993. Storymaking and Drama. Portsmouth, NH: Heinemann.

Lloyd-Jones, Richard and Andrea Lunsford, eds. 1989. The English Coalition Conference: Democracy through Language. Urbana, IL: NCTE.

Maxwell, Rhoda and Mary Miser. 1993. Teaching English to Middle and High School. New York: Macmillan.

Milner, Joseph and Lucy Milner. 1993. Bridging English. New York: Macmillan.

Moffett, James. 1981. Coming on Center: English Education in Evolution. Montclair, NJ: Boynton/Cook.

_ 1968. A Student-centered Language Arts Curriculum, Grades K-13: A Handbook for Teachers. Boston: Houghton Mifflin.

Neufeldt, Victoria, ed. 1994. Webster's New World Dictionary. New York: Macmillan.

Pugh, Sharon, Jean Hicks, Marcia Davis, and Tonya Venstra. 1992. Bridging: A Teacher's Guide to Metaphorical Thinking. Urbana, IL: NCTE.

Simmons, John, Bob Shafer, and Gail West. 1976. Decisions about the Teaching of English. Boston: Allyn \& Bacon.

Smagorinsky, Peter. 1996. Standards in Practice, Grades 9-12. Urbana, IL: NCTE.

Squire, James and Roger Applebee. 1968. High School English Instruction Today. New York: Appleton-Century-Crofts.

Squire, James. 1995. "Language Arts." Handbook of Research on Improving Student Achievement. Gordon Calwelti, ed. Arlington, VA: Educational Research Service.

Tchudi, Stephen and Diana Mitchell. 1989. Explorations in the Teaching of English. New York: HarperCollins.

Wilhelm, Jeffrey. 1996. Standards in Practice, Grades 6-8. Urbana, IL: NCTE.

\section{Literature}

Andrasick, Kathleen. 1990. Opening Texts. Portsmouth, NH: Heinemann.

Applebee, Arthur. 1996. Curriculum as Conversation: Transforming Traditions of Teaching and Learning. Chicago: University of Chicago Press.

Atwell, Nancie. 1987. In the Middle. Portsmouth, NH: Heinemann.

Beach, Richard. 1993. A Teacher's Introduction to Reader-response Theories. Urbana, IL: NCTE.

Bleich, David. 1988. The Double Perspective: Language, Literacy, and Social Relations. New York: Oxford University Press.

Bomer, Randy. 1995. Time for Meaning. Portsmouth, NH: Heinemann.

Christenbury, Leila. 1994. Making the Journey. Portsmouth, NH: Heinemann. 
Fish, Stanley. 1980. Is There a Text in This Class? Cambridge, MA: Harvard University Press.

Foster, Hal. 1993. Crossing Over. Fort Worth, TX: Harcourt Brace.

Hirsch, E. D. 1987. Cultural Literacy: What Every American Needs to Know. Boston: Houghton Mifflin.

Holland, Norman. 1989. The Dynamics of Literary Response. New York: Columbia University.

Iser, Wolfgang. 1978. The Act of Reading. Baltimore: Johns Hopkins University.

Probst, Robert. 1988. Response and Analysis. Portsmouth, NH: Boynton/Cook.

Rief, Linda. 1992. Seeking Diversity. Portsmouth, NH: Heinemann.

Rosenblatt, Louise. 1978. The Reader, the Text, and the Poem. Carbondale, IL: Southern Illinois University Press.

Simmons, John and Ed Delazain. 1992. Teaching Literature in Middle and Secondary Grades. Boston: Allyn and Bacon.

\section{Language}

Altick, Richard and Andrea Lunsford. 1984. Preface to Critical Reading. New York: Holt, Rinehart, and Winston.

Andrews, Larry. 1993. Language Exploration and Awareness. New York: Longman.

Baines, Lawrence. 1996. "From Page to Screen: When a Novel Is Interpreted for Film, What Gets Lost in the Translation?" Journal of Adolescent and Adult Literacy 39.2 (May): 612-623.

Birkerts, Sven. 1994. The Gutenberg Elegies. New York: Ballantine.

Bishop, Wendy. 1995. "Teaching Grammar for Writers in a Process Workshop Classroom." The Place of Grammar in Writing Instruction. Susan Hunter and Ray Wallace, eds. Portsmouth, NH: Heinemann.

Britton, James. 1970. Language and Learning. New York: Viking.

Clark, Robert. 1983. "Reconsidering Research on Learning from Media." Review of Educational Research 53: 445-459.

Claywell, Gina. 1995. "Reasserting Grammar's Position in the Trivium in American College Composition." The Place of Grammar in Writing Instruction. Susan Hunter and Ray Wallace, eds. Portsmouth, NH: Heinemann.

Hayakawa, S. I. 1990. Language in Thought and Action. San Diego: Harcourt Brace Jovanovich.

Irmscher, William. 1979. Teaching Expository Writing. New York: Holt, Rinehart, and Winston.

Kozma, Robert. 1991. "Learning with Media." Review of Educational Research 61.2: 179-211.

. 1994. "Will Media Influence Learning? Reframing the Debate." Educational Technology Research and Development 42.2: 31-39.

Mellon, John. 1981. "Language Competency." The Nature and Measurement of Competency in English. Charles Cooper, ed. Urbana, IL: NCTE.

Nagy, William. 1988. Teaching Vocabulary to Improve Reading Comprehension. Urbana, IL: NCTE.
Steiner, George. 1967. Language and Silence. New York: Atheneum.

Vygotsky, L. S. 1962. Thought and Language. Cambridge, MA: MIT Press.

Young, John. 1991. Totalitarian Language. Charlottesville, VA: University Press of Virginia.

Wolfram, Walt. 1991. "The Community and Language Arts." Handbook of Research on Teaching the English Language Arts. James Flood, Julie Jensen, Diane Lapp, and James Squire, eds. New York: Macmillan

\section{Composition}

Baines, Lawrence and Micah Dial. 1995. "Scripting Screenplays." English Journal 84.2 (Feb.): 86-91.

Britton, James, Tony Burgess, Nancy Martin, Alex McLeod, and Harold Rosen. 1975. The Development of Writing Abilities (11-18). London: Macmillan.

Elbow, Peter. 1973. Writing without Teachers New York: Oxford University Press.

Emig, Janet. 1971. The Composing Processes of Twelfth Graders. Urbana, IL: NCTE.

Goldberg, Natalie. 1986. Writing Down the Bones. Boston: Shambhala.

Haas-Dyson, Anne and Sarah Freedman. 1991. "Writing." Handbook of Research on Teaching the English Language Arts. James Flood, Julie Jensen, Diane Lapp, and James Squire, eds. New York: Macmillan.

Hamilton, Ian. 1990. Writers in Hollywood. New York: Harper and Row

Hawisher, Gail. 1996. Computers and the Teaching of Writing in American Higher Education, 1979-1994: A History. Norwood, NJ: Ablex.

Hillocks, George. 1986. Research on Written Composition. Urbana, IL: NCTE.

Kinneavy, James. 1971. Theories of Discourse. New York: Norton.

Kirby, Dan, Tom Liner, and Ruth Vinz. 1988. Inside Out. Portsmouth, NH: Heinemann.

Lamont, Anne. 1994. Bird by Bird. New York: Pantheon.

Murray, Don. 1987. Write to Learn. New York: Holt, Rinehart, and Winston.

Roberts, Paul. 1996. "Virtual Grub Street." Harper's (Jun.): 71-77.

Selfe, Cynthia. 1994. Literacy and Computers: The Complications of Teaching and Learning with Technology. New York: Modern Language Association.

Warren, Maria, Rachel Sutz, and Holly Williams. 1996. Unpublished research. Tallahassee, FL: The Florida State University.

Wills, Jerry, Elizabeth Stephens, and Kathryn Matthew. 1996. Technology, Reading, and Language Arts. Boston: Allyn and Bacon.

Wresch, William. 1991. The English Classroom in the Computer Age. Urbana, IL: NCTE.

\section{Speech and Drama}

Adler, Mortimer. 1983. How to Speak: How to Listen. New York: Macmillan. 
Baines, Lawrence. 1995. "Using Videotape to Assess Student Progress in English." Arizona English Bulletin 37.3 (Spring): 14-18.

Britton, James. 1970. Language and Learning. New York: Penguin.

Cooper, P. J. 1985. Activities for Teaching Speaking and Listening: Grades 7-12. Urbana, IL: ERIC.

Csikszentmihalyi, Mihaly and Reed Larson. 1984. Being Adolescent. New York: Basic Books.

Csikszentmihalyi, Mihaly, Kevin Rathunde, and Samuel Whalen. 1993. Talented Teens. New York: Cambridge University Press.

Fernandez, Thomas, ed. 1969. Oral Interpretation $\&$ the Teaching of English. Urbana, IL: NCTE.

Herman, Eldee and Sharon Ratliffe. 1972. Speech Communication in the High School. Skokie, IL: National Textbook.

Holdzkom, David, Linda Reed, Jane Porter, and Donald Rubin. 1985. Research within Reach: Oral and Written Communication. Washington, DC: National Institute of Education.

King, Nancy. 1993. Storymaking and Drama. Portsmouth, NH: Heinemann.

Moffett, James. 1968. Teaching the Universe of Discourse. Boston: Houghton Mifflin.

Moffett, James and Betty Wagner. 1992. Studentcentered Language Arts and Reading, K-13. Portsmouth, NH: Boynton/Cook.

Nystrand, Martin. 1993. "A Two-Year Study of Classroom Discourse in Eighth- and NinthGrade English." AERA Annual Meeting, Atlanta, GA, April 14.

O'Keefe, Virginia. 1995. Speaking to Think Thinking to Speak. Portsmouth, NH: Heinemann.

Roach, Carol and Nancy Wyatt. 1988. Successful Listening. New York: Harper and Row.

Spolin, Viola. 1983. Improvisation for the Theater. Evanston, IL: Northwestern University.

Wagner, Betty. 1995. "Recent Dissertations on Drama Enactment in the Classroom." NCTE Annual Convention, San Diego, CA, November 20.

\section{Critical Thinking}

Baines, Lawrence. 1996. The Teaching of Critical Thinking in Florida Schools, 1993-1996. Unpublished research. The Florida State University.

Covey, Steven. 1989. The Seven Habits of Highly Effective People. New York: Simon \& Schuster.

Marzano, Robert, Debra Pickering, Daisy Arredondo, Guy Blackburn, Ronald Brandt, and Cerylle Moffett. 1992. Dimensions of Learning. Alexandria, VA: ASCD

Ostrander, Sheila and Lynn Schroeder with Nancy Ostrander. 1979. Superlearning. New York: Delta.

Pugh, Sharon, Jean Hicks, Marcia Davis, and Tonya Venstra. 1992. Bridging: A Teacher's Guide to Metaphorical Thinking. Urbana, IL: NCTE.

Ruggiero, Vincent. 1985. Enter the Dialogue. Belmont, CA: Wadsworth Publishing.
Simon, Sidney, Leland Howe, and Howard Kirschenbaum. 1972. Values Clarification. New York: Hart Publishing.

Smagorinsky, Peter, Tom McCann, and Stephen Kern. 1987. Explorations. Urbana, IL: NCTE.

Smagorinsky, Peter. 1991. Expressions. Urbana, IL: NCTE.

1996. Standards in Practice, Grades 9-12. Urbana, IL: NCTE.

Society for Effective Affective Learning. 1995. The Roots of Learning. The Sixth International Conference, Brighton, England.

Stotsky, Sandra. 1991. "Undeveloping Independent Critical Thinking." Written Communication 8.2:193-212.

"Teacher's Guide." 1994. Read. (Apr. 8): 1.

VanTassel-Baska, Joyce, Dana Johnson, and Linda Boyce. 1996. Developing Verbal Talent. Boston: Allyn \& Bacon.

\section{Technology}

Hawisher, Gail and Paul LeBlanc. 1992. Reimagining Computers and Composition. Portsmouth, NH: Heinemann.

Negroponte, Nicholas. 1995. Being Digital. New York: Vintage Books.

Ponessa, Jeanne. 1996. "Demand for TechnologySavvy Workers Falling Short of Supply." Education Week, 15.40 (Jul. 10): 1-17.

Quality Education Data. 1996. The QED National Technology Database. Denver, CO: Peterson's.

Selfe, Cynthia. 1994. Literacy and Computers: The Complications of Teaching and Learning with Technology. New York: Modern Language Association.

Walther, Joseph. 1994. "Interpersonal Effects in Computer-mediated Interaction." Communication Research 21.4 (Aug.): 460-487.

Warren, Maria, Rachel Sutz, and Holly Williams. 1996. Unpublished research. Tallahassee, FL: The Florida State University.

Williams, Bard. 1996. The World Wide Web for Teachers. Foster City, CA: IDG Books.

Wills, Jerry, Elizabeth Stephens, and Kathryn Matthew. 1996. Technology, Reading, and Language Arts. Boston: Allyn \& Bacon.

Wresch, William. 1991. The English Classroom in the Computer Age. Urbana, IL: NCTE.

\section{Media Literacy}

Barefield, Thomas. 1996. Student Multi-media Projects on the Civil War. Student projects. Mosley High School, Panama City, Florida.

Considine, David and Gail Haley. 1992. Visual Messages. Englewood, CO: Teacher Ideas Press.

Costanzo, William. 1992. Reading the Movies. Urbana, IL: NCTE.

Darden, Christopher with Jess Walter. 1996. In Contempt. New York: HarperCollins.

Dershowitz, Alan. 1996. Reasonable Doubts. New York: Simon \& Schuster.

Fox, Roy, ed. 1994. Images in Language, Media, and Mind. Urbana, IL: NCTE. 
Gerbner, George and Nancy Signorelli. 1988. Violence and Terror in the Mass Media. New York: Greenwood Press.

Gerbner, George, Hamid Mowlana, and Herbert Schiller. 1992. Triumph of the Image: The Media's War in the Persian Gulf. Boulder, CO: Westview Press.

Morris, Barbara. 1993. "Two Dimensions of Teaching Television Literacy." Canadian Journal of Educational Communication 22.1 (Spring): 37-45.

Neal, Robert. 1913. "Making the Devil Useful." English Journal 2.10 (Dec.): 658-660.

Shapiro, Robert with Warren Larkin. 1996. The Search for Justice. New York: Warner Books.

Simpson, O.J. with Lawrence Schiller. 1996. I Want to Tell You. New York: Little, Brown.

\section{Interdisciplinary Studies}

Beane, James. 1995. "Curriculum Integration and the Disciplines of Knowledge." Phi Delta Kappan (Apr.): 616-622.

Eisner, Elliot. 1991. "The Role of the Arts in Cognition and Curriculum." Phi Delta Kappan 63.1 (Jan.): 48-52.

Fiero, Gloria. 1995. The Humanistic Tradition. Madison, WI: Brown \& Benchmark.

Gardner, Howard. 1983. Frames of Mind. New York: Basic Books.

. 1993. Multiple Intelligences. New York: Basic Books.

Greene, Maxine. 1995. "Art and Imagination." Phi Delta Kappan (Jan.): 378-382.

Hendrick, Richard. 1985. The Voyage of the Mimi: The Book. New York: Holt, Rinehart, and Winston.

Kozol, Jonathon. 1991. Savage Inequalities. New York: Crown.

Lewis, C. Anne. 1995. Believing in Ourselves: Progress and Struggle in Urban Middle School Reform. New York: The Edna McConnell Clark Foundation.

National Middle School Association. 1991. Curriculum Guide. Columbus, OH: National Middle School Association.

Panaritis, Philip. 1995. "Beyond Brainstorming: Planning a Successful Interdisciplinary Program." Phi Delta Kappan 76.8 (Apr.): 623-628.

Workman, Brooke. 1975. Teaching the Decades. Urbana, IL: NCTE. NCTE

\section{Conclusion}

Commission on English. 1965. Freedom and Discipline in English. New York: College Entrance Examination Board

Kaestle, Carl, H. Damon-Moore, L. Stedman, K. Tinsley, and W. Trollinger. 1991. Literacy in the United States. New Haven: Yale University Press.

Lawrence A. Baines teaches at Berry College in Rome, Georgia.
CALL FOR NOMINATIONS

FOR 1999 BRITTON AWARD

The Conference on English Education (CEE) is now accepting nominations for the James N. Britton Award for Inquiry within the English Language Arts.

Exemplary studies published in any format, including distributed final research reports, are eligible. The studies must be conducted by an English/language arts educator at any level-preschool through university - and may reflect on any aspect of the inquirer's own teaching. Collaborative research conducted with other practitioners will also be considered. All modes of inquiry are equally valued.

Nominations, accompanied by three copies of the published material, may be made by any language arts educator or by self-nomination not later than July $\mathbf{1}$, 1998, for studies published between January 1, 1996, and December 31, 1997. Send nominations and materials to: CEE Britton Award, NCTE, 1111 W. Kenyon Road, Urbana, IL 61801. Winners will be notified in December 1998 and announced at the 1999 Spring Conference in Cincinnati, Ohio. 